\title{
Development of Accreditation Acceleration Model We-Based Quality LKP Guarantee In Gresik District East Java Provience
}

\author{
Hery Setyo Utomo* \\ Department of Outside School Education, Faculty of Education Science, University Negeri Surabaya, Surabaya, East Jawa, Indonesia \\ a herysetyo@gmail.com \\ ${ }^{*}$ Corresponding Author \\ Whatsapp number: [08228557855]
}

How to Cite : Utomo, H., S. (2019). Development of Accreditation Acceleration Model We-Based Quality LKP Guarantee In Gresik District East Java Provience. International Journal for Educational and Vocational Studies, 1 (8), 878-883. DOI: https://doi.org/10.29103/ijevs.v1i8.2251

\section{ARTICLE HISTORY}

Received: 13 September 2019

Revised: 22 October 2019

Accepted: 4 November 2019

\section{KEYWORDS}

Development;

Acceleration Model;

Accreditation;

WEB Based;

\begin{abstract}
The quality of out-of-school education in Indonesia varies greatly and varies in quality. Efforts to improve the quality of national education by the government are always carried out in stages, planned and measured. To be able to organize quality education, every Education organizer must be accredited by BAN PAUD and PNF. There are still many LKp who are reluctant to submit accreditation requests, so that the quality of LKP also does not meet the expectations of the community and the government. The purpose of this study is to find a model for the acceleration of LKP accreditation development. The method used in this study uses a qualitative research approach, data sources obtained through in-depth interviews, direct observation and documentation. The results of this study are in the form of a product guidance acceleration of LKP accreditation. Accelerating the Development of the Accreditation Model LKP WEB-based quality assurance in Gresik Regency needs a mentoring process by a team of experts in this case the assessors are members of Pokja BAN PAUD and PNF Gresik Regency so that accreditation in Gresik Regency does not run stagnant but can run faster and quota given to the Regency Gresik can be fulfilled.
\end{abstract}

This is an open access article under the CC-BY-SA license.

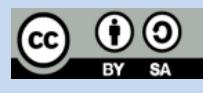

\section{INTRODUCTION}

Essential education has a very important and strategic role in managing the life of the nation and state towards a developed, just and prosperous country, especially in the effort to create competent human resources. Education is one of the $u$ factor $u$ can change the increase in welfare.

The quality of out-of-school education in Indonesia varies greatly and varies in quality. Efforts to improve the quality of national education by the government are always carried out in stages, planned and measured. To be able to organize quality education, every Education organizer must be accredited by BAN PAUD and PNF.

The accreditation policy of BAN PAUD and PNF in Indonesia is that every citizen has the right to receive quality education. To be able to carry out quality education, each unit/program and/or education unit must meet or exceed the standards carried out through accreditation activities on the suitability of each educational unit/program.
Impact Organization and Training Course that already tar accreditation is the increased credibility of CGC both on society and the government, because people will feel comfortable and trust 0 with the legality of a 0 institution 0 has one accredited. If the Institute of Course and Training (LKP ) 1 has not been accredited 0 , then the quality 1 and legality of an institution (institution's 0 quality and legal 1 status) are still 0 inviting questions 0 out of 0 society.

In accordance with the formulation of $\mathrm{F}$ problem $\mathrm{F}$, the objectives of $\mathrm{F}$ research $\mathrm{F}$ are: 1 ) What is the acceleration model for the development of WEB-based LKP quality assurance accreditation in Gresik Regency? 2) How to find solutions to LKP accreditation inhibiting factors in Gresik Regency? 3) What is the feasibility of the acceleration model of WEB-based LKP quality assurance accreditation in Gresik Regency? 4) What is the effectiveness of the acceleration model of WEB-based LKP quality assurance accreditation in Gresik Regency? In the educational environment, especially courses and training institutions the demand for quality assurance is a natural 
phenomenon because the implementation of quality education is part of public accountability. Accreditation as a controller and quality assurance ( Quality Assurance ) is the process of establishing and fulfilling management quality standards consistently and continuously, so that stakeholders get satisfaction. Quality assurance is the entire systematic plan of action that is important to provide the confidence used to satisfy certain needs of quality.

Techopedia defines: "Quality assurance (QA) is the process of verifying whether a product meets required specifications and customer expectations. QA is a process-driven approach that facilitates and defines goals regarding product design, development and production. "Quality Assurance (QA) is the process of verifying whether a product meets the specifications and expectations of consumers required. Quality assurance is a process-based approach that facilitates and defines objectives regarding design, production development and service.

According to Shewhart in Kayode, quality assurance is the process of verifying or determining whether a product or service meets or exceeds customer expectations. Quality assurance is a process-based approach with specific steps to help determine and achieve goals. This process considers design, development, production and service. According to Jones in Kayode, Quality assurance of its operational facilities through the company can provide quality control to meet quality requirements to gain confidence, both within the organization and externally to customers and authorities.

In another definition stated, Quality Assurance is refers to think's policies, attitudes, culture, actions and procedures necessary to ensure that quality is embedded, maintained and enhanced throughout all aspects of the business operations . Quality assurance refers to policies, attitudes, culture, actions and policy procedures needed to ensure that quality is embedded, maintained and improved in all aspects of business operations.

From the above definition it can be concluded that quality assurance (Quality assurance ) is a way that is done to guarantee, improve a product quality and avoid problems, provide solutions or services to consumers in order to provide satisfaction to consumers.

Courses and Training Institutions (CGC) is always trying to improve the quality and pelayananan to the public so that the people get the education that is in line with expectations and promised by the organizers of education which implies the satisfaction of the people (customers) will be the result of education. To maintain public satisfaction with the results of the course, the Institute of Course and Training can implement the ISO concept, namely what we do we must write, and what we write must be done by applying the PDCA (Plan - Do Check - Act) process approach that combines cycles : "Plan - Do - Check - Track and risk-based thinking.

Risk-based thinking helps the organization to determine the factors that can cause its quality management processes and systems to deviate from the planned results, placing preventive controls to reduce negativity and maximize the use of opportunities that arise.

Responsibility for the quality of Education especially the quality of the education process is the responsibility of all those involved in the operational process of the educational institution system, because the education community, especially educators or teaching staff and the managers and leaders of educational institutions must have concepts and strategies to continuously improve the quality of Education. through quality assurance as a guarantor in obtaining educational results, especially good student learning achievement which in turn can create quality graduates, namely graduates who are professional and competent in accordance with community expectations.

\section{METHODS}

This research was designed using the Research and Development ( $\mathrm{R} \& \mathrm{D})$ method. In the opinion of Gall and Borg (2003: 569) defines that research and development in Education are: "Educational Research and development $(R \& D)$ is a process used to develop and validate educational products. Goal of educational research is not to develop products, but rather to discover dew knowledge (through basic research) or to answer specific questions about practical problems (through applied research) ".

Development procedures include: Preliminary Preparations, including: 1) Literature study and studies of the model of the implementation of accreditation and constraints on implementation in the field; 2) Preliminary field study on the implementation of accreditation; 3) Model portrait (factual model); proceed to the Development and Validation Stage 4) Preparation of the factorial model; 5) Preparation of guidelines; 6) Practitioner validation (FGD); 7) Repairs and improvements; 8) Expert validation; 9) Improvements and improvements; and 10) Final Model of LKP accreditation in the form of Guidelines for the Development of WEB-Based LKP Quality Assurance Accreditation Acceleration Model.

Informants research are people who used to give information about the situation and the conditions setting $\mathrm{j}$ behind the research (Moleong t 2000: 97). The informant is a person who really knows problems to be $\mathrm{j}$ investigated. In the research there are two informants include: t 1). Informants key there are 3 (three),namely people really understands the problem under study. As for the meant as an informan key in research is a member of the Working Group BAN PNF ECD and Gresik, Managers and Instructors CGC 2). There are 2 (two) key informants, those who are considered to know the problem being examined, namely the LKP Inspector, the Education Office Partner Organization (HIPKI).

In qualitative research, data collection and analysis is carried out during the study simultaneously while also 
analyzing 1 data. The success and success of a research is highly dependent on how detailed, accurate, and \% extent of fieldwork (Bogdan and \% Biklen, 1982). On entry thefield can bedone through observation /participan ts then 1 followed by one interview with a business unit of PPR, assessors BAN ECD Working Group members and $\mathrm{PNF}$ as well as with the District Overseer, reviewing one data source 1 documentary, as well as the activities of collecting other data related to recording in the field is an important activity that supports the success of research.

Quantitative Data Collection Techniques are carried out in a variety of settings and various sources in various ways. When viewed from the settings data can be collected in natural settings, in laboratories with experiments, at home with various respondents, and others.

Data collection is a stage of the research process in which researchers apply scientific methods and techniques in order to collect systematic data for analytical purposes. The researcher must refer to the research design, problem formulation and also the purpose of the research before determining what methods should be used to collect data.

Qualitative research is research that is used to reveal problems in the working lives of government, private, social, youth, women's, sports, arts and cultural organizations, etc. so that they can be used as a policy to be implemented for mutual welfare. In terms of the way or data collection techniques, the data collection techniques can be done by interview, questionnaire (questionnaire) and observation.

The steps of the preparation and development of instruments according to Hadjar, in a particular study, researchers must follow the steps of instrument development, namely: 1) Defining variables; 2) Describe variables into more detailed indicators; 3) Arranging points; 4) Carry out trials; 5) Analyzing the validity (validity) and reliability (reliability).

Data analysis technique analysis model Creswell exsplaind that analysis of data is a process on going that required refleksi kept constantly on the data, asking questions analytically, and write short notes throught out the study. Analysis of the data for the the data that qualitative done by way of describing it with words I or a sentence in accordance with the results of the data obtained with a wide range and with the techniques of collecting data that varies as observation, interviews, and documentation. the techniques of collecting data that varies as observation,interviews, and documentation . Data extracted 's e way continuously so that the data collected in accordance with the needs of research.

\section{RESULTS AND DISCUSSIONS}

Submission of accreditation can basically be done at any time. All accreditation registrations are done through the Sispena application version 1.2 . with the requirement that the Course and Training Institution Unit (LKP) already have an NPSN (National Unit Number) and fill in Dapodik (Basic Education Data) and LKP operational permits are still valid and not expire (dead).

The accreditation process will begin at the examination of the completeness of the accreditation files / documents using the sispena application at the Classification of Accreditation Request (KPA) stage carried out by the BAN PAUD secretariat and the Provincial PNF, at the KPA process the secretariat checks for the existence of Major documents and a minimum grade of 392 (PAUD) ), 472 (LKP) and 438 (PKBM / SKB) and examine the completeness of documents attached by the Institution, including Application, Declaration of Absolute Responsibility (SPTJM), attachment to 8 SNP documents and attachment of supporting photos. If there are still documents that have not been uploaded, the BAN PAUD secretariat and the Provincial PNF immediately contact the agency to complete.

After completing the Sispena application, the next process is PKPA (Appropriate Accreditation Appraisal Assessment) conducted by the appointed Assessors and gets a letter of assignment from BAN PAUD and PNF, if PKPA passes, the next process is the LKP Unit will be visited by 2 assessors who got an assignment letter from BAN PAUD and PNF. After the visitation process has passed, then the Validation and Verification process will be carried out by the appointed assessor and get an assignment letter from BAN PAUD and PNF. The next process is to submit the results of the Validation and Verification process to the Plenary Meeting of BAN PAUD and $\mathrm{PNF}$ to convene and determine the results of accreditation that is accredited A, B, C or not accredited.

The cycle of LKP accreditation activities in Gresik Regency can be described as follows:

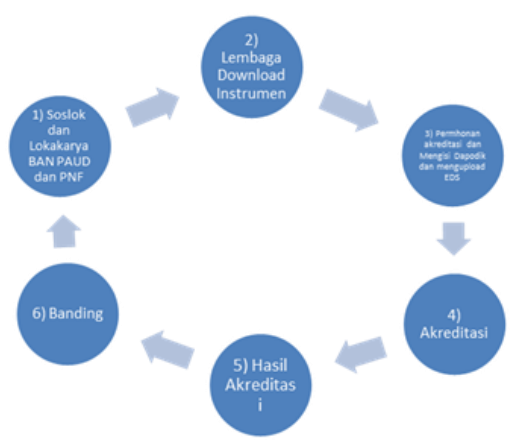

Figure 1. Cycle of the BAN PAUD and PNF accreditation process

The stages of LKP BAN PAUD and PNF accreditation activities where after LKP managers participated in the Socialization and Workshop (Soslok) activities and were ready to submit accreditation requests are as follows: a) Accreditation information can be viewed on the BAN PAUD and PNF website www.banpaudpnf.or.id ; b) Fill in Dapodik which is an accreditation database as like in the link https://dapo.paud-dikmas.kemdikbud.go.id; c) Downl 
oad the instrument of accreditation LKP include grating instrument CGC accreditation, assessment rubrics a ccreditation $\quad \mathrm{CGC}$ and subsequently apply for accreditation, fill statement and documents and download browse Self Evaluation Unit (EDS) online. If all documents are complete and correct, then the eligibility inspection process will be conducted for the accreditation request by the Assessor assigned by BAN PAUD and PNF; d) Examination of the Eligibility for Program and/or Unit Accreditation Requests (PKPA) to ensure the eligibility of entry into the next stage of accreditation; e) Visitation, Validation and Verification to determine the results of the accreditation and the announcement of the results of accreditation by BAN PAUD and PNF and an Accreditation certificate is issued.

The process of accreditation BAN pelaksaaan ECD and $\mathrm{CGC}$ is Online presented in the figure below.

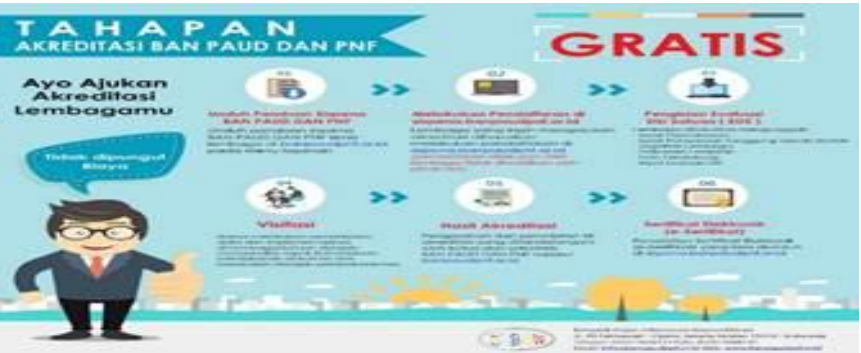

Figure 2. Flow of PAUD and PNF accreditation processes

While the results of the Research Model for the Acceleration of BAN PAUD and PNF Accreditation Development are presented in the figure below:

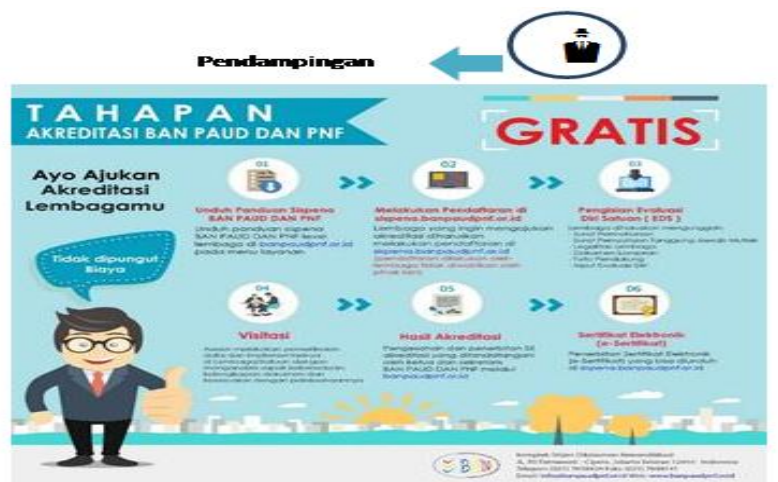

Figure 3. Process flow of accelerating the development of WEB-based quality assurance LKP accreditation models in Gresik Regency, East Java Province.

The results of researchers in conducting observations and in-depth interviews as well as exploring the potential and major problems in the accreditation process are the course and training institute units experiencing problems or obstacles when completing EDS, where when the LKP Operator uploads 8 National Education Standards in the form of softcopy, LKP operators must changing files with smaller sizes or converting files with DOC types changed in PDF format and changing photos of supporting documents with a resolution of 100 mega pixcel encountered many obstacles. This is where there is a need for assistance from a team of experts in this case the Assessors members of the BAN PAUD Working Group and PNF can help with these difficulties so that filling in the EDS can run completely and correctly.

Assistance tasks in filling the Unit Self Evaluation are:

1. Identifying the constraints in this case is the solution so that school operators can upload PDF attachments in a maximum of $2 \mathrm{MB}$ per standard by attaching documents by attaching the most important pages to represent each standard and complete documents are saved and shown when the Visitation Team conducts an assessment.

2. Motivating LKP Units to keep their enthusiasm and work in a measured manner so that the accreditation application process can be fulfilled by completing the filling in EDS.

3. Companion assessors can help increase mastery of computer technology such as how to connect HP Hostpot to a laptop and how to convert DOC files to $\mathrm{PDF}$ and how to reduce image resolution so that it can be uploaded to the SISPENA application system.

4. Accompaniment assessors continue to provide professional assistance by sticking to the Code of Ethics of BAN PAUD and PNF Assessors.

5. Ensuring that the EDS has been completely and correctly filled in so that it can proceed to the process of Classification of Accreditation Requests made by BAN of East Java Province.

With the assistance provided by the Assessors of the BAN PAUD and PNF Gresik District members, the accreditation process can proceed faster, according to the targets and quota set by the BAN PAUD and the Provincial PNF. This is in accordance with the concept of assistance as a strategy that is commonly used by governments and non-profit institutions in an effort to improve the quality and quality of human resources, so as to identify themselves as part of the problems experienced and seek to find alternative solutions to the problems encountered. The ability of human resources is strongly influenced by his own empowerment. Therefore, empowerment activities are very needed in each mentoring activity. Suharto (2005, page: 93 ) outlines that mentoring is a strategy that greatly determines the success of community empowerment programs, he further said in Payne's quote (1986) that mentoring is a strategy that prioritizes "making the best of the available resources".

\section{CONCLUSION}

1. Preparation of LKP BAN PAUD and PNF accreditation in Gresik Regency, the activities begin with the Socialization and Workshop held in collaboration with BAN PAUD and PNF in East Java Province and the Gresik District Education Office, in this case BAN PAUD and PNF Gresik District, 
henceforth the LKP Unit submits the request for accreditation by filling out the Satun Self Evaluation (EDS) without any mentoring process, so for Institutions that experience problems and problems, it cannot continue to fill in EDS completely and correctly which means the application process will be stopped.

2. The inhibiting factors of the accreditation process in Gresik Regency are:

a. Management that still uses barber management where the Manager concurrently acts as an instructor, marketing officer and cleaning service;

b. Funding factors that are still not enough to finance accreditation preparations;

c. LKP infrastructure that has not been supported such as old school laptops;

d. Socialization activities and workshops conducted by BAN PAUD and PNF of East Java Province that are not sustainable and there is no follow up of assistance;

e. The results or rewards from Accredited Status cannot be felt directly by the Education Unit, especially the form of assistance from the Government; and

f. The qualifications of LKP Managers and instructors are still low in the sense that they are not linear with the competencies they practice.

3. Supporting factors for the LKP BAN PAUD and PNF accreditation process in Gresik Regency are:

a. The existence of the BAN PAUD and PNF websites is very helpful and needed by LKP, so that what is needed by A sesion is already available on the Website, such as: Instruments, Rubrics; and materials related to accreditation;

b. There have been many Institutional Units that have applied for Accreditation, so that they can ask questions and learn from Institutions that have been accredited, especially those Accredited A with an ATM system (Observe, Imitate and Modify) and create new ones;

c. With the formation of LWGs in each Regency / City it is a positive thing for Asesi to consult before the forms are submitted to BAP PAUD and $\mathrm{PNF}$ and ready to carry out the assistance process so that LKP units are ready to upload 8 SNPs correctly and completely;

d. By using Sispena, the implementation of accreditation has become easier, faster, higher quality, and more connected with other educational advisory units.

e. The existence of the Sub-District Inspector if he really works and carries out the accreditation assistance process;

f. The role of Partner organizations such as HIPKI, FK LKP, HISPPI has a very strategic role because in these organizations can exchange information and learn how to use IT in the accreditation process and sharing ways of filling in Dapodik and Sispena especially in terms of uploading EDS (Self Evaluation Unit) .

4. Accelerating the Development of the WEB-based Quality Assurance LKP Accreditation Model in Gresik Regency begins with the activities of the Socialization and Workshop on Accreditation of BAN PAUD and PNF, followed by filling in the EDS (Self-Evaluation Unit) if it passes, followed by the PKPA (Accreditation Appeal Checking) process by the Assessors get an assignment letter from BAN PAUD and PNF, if passed PKPA is continued with visitation, Validation and Verification to continue the Plenary Meeting of BAN PAUD and PNF to determine the results of accreditation and so far it has been stagnant.

\section{Suggestions}

Accelerating the Development of the Accreditation Model LKP WEB-based quality assurance in Gresik Regency needs a mentoring process by a team of experts in this case the assessors are members of Pokja BAN PAUD and PNF Gresik Regency so that accreditation in Gresik Regency does not run stagnant but can run faster and quota given to the Regency Gresik can be fulfilled.

\section{REFERENCES}

Borg, WR \& Gall, MD Gall. (1983). Educational Research: An Introduction , Fifth Edition. New York: Longman

Borg, Walter $\mathrm{R}$ and Meredith Damien Gal. (1979). Educational

Research An Introduction. Fourth Edition. New York: Longman.

Ministry of National Education, (2003). Law Number 20 Year 2003, Concerning the National Education System. Jakarta: Ministry of National Education.

Faisal Sanapiah, (1981). Outside School Education. Surabaya:

CV. National

Business.https://dpphipki.org

http://www.infokursus.net/datakursus

Jonathan, Sarwono, (2006). Quantitative and Qualitative Research Methods, Yogyakarta: Graha Science.

Joesoef Soelaiman, (2004). Basic Concepts of Non-School Education. Jakarta: PT. Earth Literacy.

Mashuri and M. Zainudin, (2009). Research Methods: Practical and Applicative Approaches. Bandung: Refika Aditama.

Mustaji (2010). Managing Training for Performance Improvement Efforts in the Field of Business and Education. Surabaya: Unesa University Press. Postgraduate of Surabaya State University. (2017). Guidelines for writing a thesis and a dissertation. Surabaya. 
Regulation of the Minister of Education and Culture of the Republic of Indonesia Number 52 Year 2015 Concerning the National Accreditation Board for Early Childhood Education and Non-Formal Education. Jakarta: Ministry of Education and Culture, 2015.

Philip H. Coombs. (1982). What Is Educational Planning , (translation). Jakarta: Bhatara Karya Akasara

Philip H. Coombs, Government Regulation of the Republic of Indonesia Number 19 of 2005 concerning: National Education Standards, Jakarta: Ministry of National Education, 2005

Riyanto, Yatim. (2010). Educational Research Methodology. Surabaya: SIC Publisher.

Riyato, Yatim (2007). Qualitative and Quantitative Education Research Methodology. Surabaya: Unesa University Press.

Rahayu and Ardani (2004). Observation and Interview. Madang: Bayu Media Publishing.

Robbins and Coulter. 2002. Management, 7 th edition. New Jersey: Prentice Hall. Inc.

Setiwan, Ebta. (2015). Big Indonesian Dictionary . Online: http://kbbi.web.id/implementation. Accessed November 8, 2015.

Sugiono, (2015). Research and Development Methods: Research and Development. Bandung: Alfabeta.

Sudjana, Djudju. (2004). Management of Educational Programs; For Non-Formal Education and Human Resource Development. Bandung: Falah Production.

The 1945 Constitution, (Semarang: Thoha Putra, 2005) Republic of Indonesia Law. Number. 20 of 2003 concerning the National Education System, Jakarta:

Sinar Grafika, 2009. www.banpaudpnf.or.id 